\title{
Pengaruh Kompetensi dan Independensi Terhadap Kinerja Auditor Pemerintah Kabupaten Luwu Timur
}

\author{
Salju ${ }^{1}$ \\ Rismawati $^{2}$ \\ Muhammad Dirga Bachtiar ${ }^{3}$ \\ No. HP $082187494777^{1}, 081334488341^{2}$ \\ ${ }^{1}$ Alamat Korespondensi: Jl. K. H. A. Rasak, No. 59 Palopo \\ Email: sljstie@yahoo.com
}

\begin{abstract}
Abstrak
Penelitian ini bertujuan untuk mengetahui apakah kompetensi dan independensi berpengaruh terhadap kinerja auditor pemerintah Kabupaten Luwu Timur. Sampel dalam penelitian ini sebanyak 25 orang responden sebagai auditor pemerintahan dan analisis menggunakan alat analisis statistik regresi linier berganda yang dilakukan untuk pengujian data meliputi pengujian secara parsial (uji t) dan pengujian secara simultan (ujif).

Secara parsial, hasil penelitian menunjukkan bahwa variabel kompetensi $\left(X_{1}\right)$ dan independensi $\left(X_{2}\right)$ tidak berpengaruh signifikan terhadap kinerja auditor pemerintah daerah.

Hasil uji $F$ menunjukkan bahwa secara simultan semua variabel independen berpengaruh signifikan terhadap kinerja auditor pemerintah daerah. Hal ini dapat dilihat pada nilai signifikansi $F_{\text {hitung }}$ adalah 10,586 dan signifikan penelitian lebih kecil 0,05( 0,001 < 0,05). Nilai koefisien determinasi menunjukkan angka sebesar 0,455 atau 45,5\% yang berarti bahwa variabel independen hanya mampu memberikan kontribusi sebesar 45,5\% terhadap kinerja auditor pemerintah kabupaten Luwu Timur dan sisanya $54,5 \%$ dipengaruhi oleh faktor-faktor lain yang tidak dimasukkan dalm penelitian ini.
\end{abstract}

Kata kunci: Kompetensi, Independensi, Kinerja Auditor Pemerintah daerah.

\section{Pendahuluan}

Pelaksanaan akuntabilitas sektor publik terhadap terwujudnya good governance di Indonesia semakin meningkat dan harus diterapkan. Hal tersebut harus dilaksanakan, karena beberapa penelitian menunjukkan bahwa terjadinya krisis ekonomi di Indonesia ternyata disebabkan oleh buruknya pengelolaan dan birokrasi.

Menurut Mardiasmo (2005), terdapat tiga aspek utama yang mendukung terciptanya kepemerintahan yang baik (good governance), yaitu pengawasan, pengendalian, dan pemeriksaan. Pengawasan merupakan kegiatan yang dilakukan oleh pihak di luar eksekutif, yaitu masyarakat dan Dewan Perwakilan Rakyat Daerah (DPRD) untuk mengawasi kinerja pemerintahan. Pengendalian (control) adalah mekanisme yang dilakukan oleh eksekutif untuk menjamin bahwa sistem dan kebijakan manajemen dilaksanakan dengan baik sehingga tujuan organisasi dapat tercapai. Sedangkan pemeriksaan (audit) merupakan kegiatan yang dilakukan oleh pihak yang memiliki independensi dan memiliki kompetensi profesional untuk memeriksa apakah hasil kinerja pemerintah telah sesuai dengan standar yang ditetapkan.

Salah satu unit yang melakukan audit/pemeriksaan terhadap pemerintah daerah adalah inspektorat daerah. Menurut Falah (2005), inspektorat daerah mempunyai tugas menyelenggarakan kegiatan pengawasan umum pemerintah daerah dan tugas lain yang diberikan kepala daerah, sehingga dalam tugasnya 
inspektorat sama dengan auditor internal. Menurut Mardiasmo (2005), audit internal adalah audit yang dilakukan oleh unit pemeriksa yang merupakan bagian dari organisasi yang diawasi.

Menurut Boynton dalam Rohman (2007), fungsi auditor internal adalah melaksanakan fungsi pemeriksaan internal yang merupakan suatu fungsi penilaian yang independen dalam suatu organisasi untuk menguji dan mengevaluasi kegiatan organisasi yang dilakukan. Selain itu, auditor internal diharapkan pula dapat lebih memberikan sumbangan bagi perbaikan efisiensi dan efektivitas dalam rangka peningkatan kinerja organisasi. Dengan demikian auditor internal pemerintah daerah memegang peranan yang sangat penting dalam proses terciptanya akuntabilitas dan transparansi pengelolaan keuangan di daerah.

Peran dan fungsi Inspektorat Provinsi, Kabupaten/Kota secara umum diatur dalam pasal 4 Peraturan Menteri Dalam Negeri No 64 Tahun 2007. Dalam pasal tersebut dinyatakan bahwa dalam melaksanakan tugas pengawasan urusan pemerintahan, Inspektorat Provinsi, Kabupaten/Kota mempunyai fungsi sebagai berikut: pertama, perencanaan program pengawasan; kedua, perumusan kebijakan dan fasilitas pengawasan; dan ketiga, pemeriksaan, pengusutan, pengujian, dan penilaian tugas penga wasan.

Di pemerintahan, peran auditor internal dinilai masih belum berarti. Widyananda (2008), hasil audit Badan Pemeriksa Keuangan atas Laporan Keuangan Pemerintah Pusat tahun 2007 masih menemukan banyaknya kelemahan terkait sistem pengendalian intern ketidakpatuhan pada peraturan perundang-undangan. Terkait dengan hal tersebut, Widyananda (2008), mengungkapkan pentingnya merevitalisasi peran auditor internal pemerintah untuk menegakkan good governance. Dengan demikian, dapat disimpulkan bahwa kinerja auditor internal masih belum optimal.

Kinerja auditor merupakan tindakan atau pelaksanaan tugas pemeriksaan yang telah diselesaikan oleh auditor dalam kurun waktu tertentu. Trisnaningsih (2007), mengemukakan bahwwa Kinerja (prestasi kerja) dapat diukur melalui pengukuran tertentu (standar), dimana kualitas adalah berkaitan dengan mutu kerja yang dihasilkan, sedangkan kuantitas adalah jumlah hasil kerja yang dihasilkan dalam kurun waktu tertentu, dan ketepatan waktu adalah kesesuaian waktu yang telah direncanakan.

Sri Lastanti (2005), kompetensi seorang auditor sangat dibutuhkan dalam melakukan audit. Kompetensi seorang auditor diuji dari pengetahuan dan pengalaman yang dimiliki. Seorang auditor harus memiliki pengetahuan yang diukur dari seberapa tinggi pendidikan seorang auditor, karena dengan demikian auditor akan mempunyai semakin banyak pengetahuan (pandangan) mengenai bidang yang digelutinya sehingga dapat mengetahui berbagai masalah secara makin mendalam. Seorang auditor juga harus berpengalaman dalam melakukan audit. Semakin lama auditor melakukan pemeriksaan maka semakin banyak pengalaman yang dimiliki sebagai seorang auditor. Pengalaman kerja sebagai seorang auditor hendaknya memiliki keunggulan dalam mendeteksi kesalahan, memahami kesalahan secara mendalam, dan mencari penyebab masalah tersebut. 
Audit harus dilaksanakan oleh seseorang atau lebih yang memiliki keahlian dan pelatihan teknis yang cukup sebagai auditor. Auditor harus meningkatkan pengetahuan mengenai metode dan teknik audit serta segala hal yang menyangkut pemerintahan seperti organisasi, fungsi, program, dan kegiatan pemerintahan. Keahlian auditor menurut Tampubolon (2005), dapat diperoleh melalui pendidikan dan pelatihan yang berkelanjutan serta pengalaman yang memadai dalam melaksanakan audit.

Selain keahlian audit, seorang auditor juga harus memiliki independensi dalam melakukan audit agar dapat memberikan pendapat atau kesimpulan yang apa adanya tanpa ada pengaruh dari pihak yang berkepentingan.

Sikap mental independen sama pentingnya dengan keahlian dibidang praktik akuntansi dan prosedur audit yang harus dimiliki oleh setiap auditor. Auditor tidak hanya berkewajiban mempertahankan sikap mental independen, tetapi juga harus menghindari hal-hal yang dapat mengakibatkan independensinya diragukan masyarakat. Sikap mental independen auditor menurut masyarakat inilah yang tidak mudah diperoleh olehnya.

Kompetensi dan independensi yang dimiliki auditor dalam penerapannya akan terkait dengan etika. Nugrahaningsih (2005), mengemukakan bahwa Akuntan mempunyai kewajiban untuk menjaga standar perilaku etis tertinggi mereka kepada organisasi dimana mereka bernaung, profesi mereka, masyarakat dan diri mereka sendiri dimana akuntan mempunyai tanggungjawab menjadi kompeten dan untuk menjaga integritas dan obyektivitas mereka.
Trisnaningsih (2007), menyatakan bahwa pemahaman good governance dapat meningkatkan kinerja auditor jika auditor tersebut selama dalam pelaksanaan pemeriksaan selalu menegakkan sikap independensi.

Penelitian-penelitian yang terkait dengan kinerja auditor, salah satunya dilakukan oleh Sapariyah (2011) melakukan penelitian tentang pengaruh good governance dan independensi auditor terhadap kinerja auditor dan komitmen organisasi. Hasil penelitiannya menunjukkan bahwa: 1) Good Governance berpengaruh positif dan signifikan terhadap Komitmen Organisasi, 2) Independensi Auditor berpengaruh positif tapi tidak signifikan terhadap Komitmen Organisasi, 3) Good Governance berpengaruh positif dan signifikan terhadap Kinerja Auditor, 4) Independensi Auditor berpengaruh positif tapi tidak signifikan terhadap Kinerja Auditor, 5) Komitmen Organisasi berpengaruh positif dan signifikan terhadap Kinerja Auditor, 6) Dari hasil analisis jalur adalah Jalur Langsung (direct effect) Good Governance berpengaruh positif dan signifikan terhadap Kinerja Auditor. Variabel Komitmen Organisasi tidak mampu sebagai variabel intervening Good Governance terhadap Kinerja Auditor, karena jalur langsung memiliki koefisien dominan, tapi mampu menjadi variabel intervening independensi auditor terhadap kinerja auditor. Nurul Arifah (2012) melakukan penelitian tentang pengaruh independensi auditor, komitmen organisasi, dan gaya kepemimpinan terhadap kinerja auditor. Hasil penelitiannya menunjukkan bahwa independensi auditor, komitmen organisasi, dan gaya kepemimpinan berpengaruh positif dan signifikan terhadap kinerja auditor. 
Mengacu dari penelitian-penelitian di atas, dalam penelitian ini peneliti akhirnya tertarik untuk meneliti tentang kinerja auditor yang dipengaruhi oleh kompetensi dan independensi auditor. Perbedaan penelitian ini dengan penelitian terdahulu yaitu subjek penelitian dan beberapa variabel penelitian.

\section{Metode Penelitian}

Penelitian ini dilakukan pada Kantor Inspektorat pemerintahan Kabupaten Luwu Timur. Yang berlokasikan jalan Dr. Sam Ratulangi KM2 Puncak Indah Malili Sulawesi Selatan.

Jenis data yang digunakan dalam penelitian ini yaitu data kuantitatif. Menurut Sugiyono (2007) Data kuantitatif adalah yaitu jenis data yang berbentuk angka atau bilangan. Sesuai dengan bentuknya, data kuantitatif dapat diolah atau dianalisis menggunakan teknik perhitungan matematika atau statistika. Sumber data dalam penelitian ini berasal dari data primer. Menurut Sekaran (2006) Data primer adalah data yang dikumpulkan untuk penelitian dari tempat aktual terjadinya peristiwa. Data primer diperoleh dari melalui kuesioner atau daftar pertanyaan yang disebar kepada para responden.

Menurut Sekaran (2006) populasi adalah keseluruhan kelompok orang, kejadian, atau hal minat yang ingin peneliti investigasi, sedangkan sampel adalah sebagian dari populasi, sampel terdiri atas sejumlah anggota yang dipilih dari populasi. Populasi dan sampel dalam penelitian ini adalah seluruh auditor internal pemerintah yang terdiri dari 25 orang di Kantor inspektorat Kabupaten Luwu Timur.
Metode pengumpulan data yang digunakan dalam penelitian ini adalah metode survei. Menurut Indriantoro dan Supomo dalam Yusman (2013) Metode survei merupakan metode pengumpulan data primer yang menggunakan pertanyaan lisan atau tertulis. Teknik pengumpulan data dalam metode survei pada penelitian ini menggunakan kuesioner. Menurut Sekaran (2006) Kuesioner adalah daftar pertanyaan atau pernyataan tertulis yang telah dirumuskan sebelumnya yang akan responden jawab, biasanya dalam alternatif yang didefinisikan dengan jelas.

Data yang digunakan adalah data primer, yang berupa persepsi para responden terhadap variable-variabel yang digunakan. Modus komunikasi untuk memperoleh data dari responden dalam penelitian ini menggunakan kuesioner. Kuesioner yang diberikan berisi sejumlah pertanyaan yang akan diberikan kepada seluruh Auditor internal yang berjumlah 25 orang di inspektorat Kabupaten Luwu Timur.

Variabel penelitian menurut Sugiyono (2012:2) adalah segala sesuatu yang berbentuk apa saja yang ditetapkan oleh peneliti untuk dipelajari sehingga diperoleh informasi tentang hal tersebut, kemudian ditarik kesimpulannya. Variabel penelitian menurut Sugiyono (2012:2) adalah segala sesuatu yang berbentuk apa saja yang ditetapkan oleh peneliti untuk dipelajari 
sehingga diperoleh informasi tentang hal tersebut, kemudian ditarik kesimpulannya.Variabel penelitian terdiri dari variabel bebas/Independen dan variabel terikat/dependen. Yang menjadi variabel bebas dalam penelitian ini adalah Kompetensi dan Independensi serta variabel terikatnya adalah Kinerja Auditor, sebagai berikut :

\section{Kompetensi (X1)}

kompetensi sebagai keterampilan dari seorang ahli. Dimana ahli didefinisikan sebagai seseorang yang memiliki tingkat ketrampilan tertentu atau pengetahuan yang tinggi dalam subyek tertentu yang diperoleh dari pelatihan dan pengalaman.

Indikator pengukuran dari kompetensi adalah mutu personal, Pengetahuan Umum, dan keahlian khusus. Persepsi responden terhadap masing-masing indikator tersebut diukur dengan skala Likert 1-5.

2. Independensi (X2)

Independensi merupakan suatu sikap yang harus bebas dari hambatan, memberikan opini yang objektif, tidak dibatasi, dan melaporkan masalah yang sebenarnya, bukan berdasarkan keinginan eksekutif atau lembaga.

Indikator pengukuran dari independensi adalah independensi penyusunan program, independensi pelaksanaan pekerjaan, dan independensi pelaporan. Persepsi responden terhadap masing-masing indikator tersebut diukur dengan skala Likert 1-5.

3. Kinerja Auditor (Y)
Kinerja auditor merupakan hal yang sulit untuk diukur sehingga membuatnya menjadi suatu hal yang sensitif bagi pelaku individual yang melakukan audit. Secara teoritis kinerja auditor sering di hubungkan dengan tanggung jawab, kepentingan masyarakat, kompetensi dan independensi.

Namun dalam penelitian ini kinerja auditor diukur dengan menggunakan indikator yaitu Hasil dan perilaku. Persepsi responden terhadap masing-masing indikator tersebut diukur dengan skala Likert 1-5.

\section{Metode Analisis Data}

1. Uji kualitas data

Berhubung metode pengumpulan data dalam penelitian ini menggunakan kuesioner, maka sebelum data hasil kuesioner tersebut digunakan untuk pengujian hipotesis, terlebih dahulu dilakukan uji validitas dan uji reliabilitas. Hal ini diperlukan agar hasil akhir dan kesimpulan yang dikemukakan peneliti tidak akan keliru dan memberikan gambaran yang tidak jauh berbeda dengan keadaan yang sebenarnya serta hipotesis yang digunakan juga akan mengenai sasarannya.

Sugiyono (2007) menjelaskan bahwa uji validitas merupakan alat ukur yang digunakan untuk mendapatkan data itu valid atau dapat digunakan untuk mengukur apa yang seharusnya diukur, sedangkan uji reliabilitas digunakan untuk menetapkan apakah instrumen yang dalam hal ini kuesioner dapat digunakan lebih dari satu kali, paling tidak oleh responden yang sama akan menghasilkan data yang konsisten. 
Ghozali (2009) uji validitas dilakukan dengan menggunakan teknik Pearson Correlation, yaitu dengan cara menghitung korelasi antara skor masing-masing butir pernyataan/pertanyaan dengan total skor, jika korelasi antara skor masing-masing butir pernyataan dengan total skor mempunyai tingkat signifikansi di bawah 0,05 maka butir pernyataan tersebut dinyatakan valid dan sebaliknya . Sedangkan uji reliabilitas dilakukan dengan menggunakan teknik Cronbach Alpha, suatu instrumen dapat dikatakan reliabel apabila memiliki koefisien keandalan atau Cronbach Alpha >0,60.

1. Pengujian asumsi klasik

Sebelum dilakukan pengujian hipotesis yang menggunakan analisis regresi berganda maka diperlukan pengujian asumsi klasik. Untuk mendapatkan nilai pemeriksa yang tidak bias dan efisien (Best Liniar Unbias Estimator/BLUE) dari satu persamaan regresi berganda dengan metode pangkat kuadrat terkecil (Ordinary Least Squares/OLS) perlu dilakukan pengujian untuk mengetahui model regresi yang dihasilkan memenuhi persyaratan asumsi klasik. Uji asumsi klasik untuk regresi berganda yang sering digunakan adalah sebagai berikut:

a. Uji normalitas, untuk menguji apakah dalam sebuah model regresi, variabel dependen, variabel independen atau keduanya mempunyai distribusi normal atau tidak. Model regresi yang baik adalah distribusi data normal atau mendekati normal. Dalam penelitian ini, untuk mendeteksi normalitas dapat dilakukan dengan pengujian Histogram. Ghozali (2009) menyatakan bahwa Histogram, yaitu membandingkan antara data observasi dengan distribusi yang mendekati distribusi normal dan grafik normal probability plot yaitu distribusi normal akan membentuk suatu garis lurus diagonal. Apabila data yang digunakan terdistribusi normal, maka residual plots akan mengikuti garis normalitas dan berada di sekitar garis.

b. Singgih Santoso (2001), uji multikolinearitas, untuk menguji apakah pada model regresi ditemukan adanya korelasi yang tinggi atau sempurna antar variabel independen. Jika terjadi korelasi maka dinamakan terdapat problem multikolinearitas. Model regresi yang baik seharusnya tidak terjadi korelasi diantara variabel independen. Ghozali (2009), Multikolinearitas dapat dilihat pada tolerance value atau variance inflation factor (VIF). Apabila tolerance value dibawah 0,10 atau nilai VIF diatas 10 maka terjadi multikolinearitas. Apabila ternyata terdapat multikolinearitas, maka salah satu variabel harus dikeluarkan dari persamaan.

c. Ghozali (2009), uji heterokedastisitas, untuk mengetahui apakah dalam sebuah model regresi terjadi ketidaksamaan varian dari residual antara satu pengamatan dengan pengamatan yang lain. Suatu model regresi yang baik harus bebas dari masalah heterokedastisitas. Untuk menguji ada tidaknya masalah heterokedastisitas 
dapat dilakukan dengan melihat apakah terdapat pola tertentu pada grafik scttterplot antara SRESID dan ZPRED dimana sumbu $\mathrm{Y}$ adalah $\mathrm{Y}$ yang telah diprediksi dan sumbu $\mathrm{X}$ adalah residual (Y prediksi - Y sesungguhnya). Apabila terdapat pola tertentu secara teratur pada grafik scatterplot maka ada indikasi bahwa terdapat heterokedastisitas. Apabila tidak terdapat pola yang jelas, maka tidak terdapat heterokedastisitas.

2. Pengujian Hipotesis

Sugiyono (2007), metode analisis yang digunakan dalam penelitian ini adalah deskriptif kuantitatif. Metode analisis deskriptif adalah statistik yang digunakan untuk menganalisis data dengan cara mendeskripsikan atau menggambarkan data yang telah terkumpul sebagaimana adanya tanpa bermaksud membuat kesimpulan yang berlaku untuk umum atau generalisasi.

Untuk pengujian hipotesis dalam penelitian ini, menggunakan alat analisis statistik regresi linear berganda dengan menggunakan alat bantu SPSS versi 21.0. Persamaan regresi linear berganda ini mengandung makna bahwa dalam suatu persamaan regresi meramalkan bagaimana keadaan (naik turunnya) variabel dependen, bila dua atau lebih variabel independen sebagai indikator. Sugiyono (2007), menggambarkan persamaan umum regresi linear berganda adalah sebagai berikut:

$$
Y=a+b_{1} X_{1}+b_{2} X_{2}+e
$$

\section{Keterangan :}

Y : kinerja auditor

$\mathrm{X}_{1}$ : kompetensi

$\mathrm{X}_{2}$ : Independensi

a : Konstanta

$b_{1,2}:$ Koefisien Regresi

e : error

Hasil pengujian statistik dengan menggunakan regresi linear berganda yang perlu dianalisis dan dibahas adalah koefisien determinasi $\left(R^{2}\right)$, uji parsial (uji t) dan uji simultan (uji F), akan dijelaskan sebagai berikut:

a. Koefisien Determinasi $\left(\mathrm{R}^{2}\right)$

Ghozali (2009), koefisien determinasi $\left(\mathrm{R}^{2}\right)$ digunakan untuk menguji besarnya persentase variasi variabel dependen yang dapat dijelaskan oleh variasi variabel independen. Nilai koefisien determinasi adalah antara nol dan satu. Nilai $R^{2}$ yang kecil berarti kemampuan variabel-variabel independen dalam menjelaskan variasi variabel dependen amat terbatas. Nilai yang mendekati satu berarti variabel-variabel independen memberikan hampir semua informasi yang dibutuhkan untuk memprediksi variasi variabel independen.

Kelemahan mendasar penggunaan koefisien determinasi adalah bias terhadap jumlah variabel independen yang dimasukkan ke dalam model. Setiap tambahan satu variabel independen, maka $\mathrm{R}^{2}$ pasti meningkat, tidak peduli apakah variabel tersebut berpengaruh terhadap variabel dependen. 
Hasan (2011) dalam Amrin

(2013), untuk menentukan keeratan hubungan atau korelasi antar variabel tersebut, kriteria yang dapat dijadikan sebagai patokan adalah sebagai berikut:

1. $\mathrm{KK}=0$, tidak ada korelasi;

2. $0<\mathrm{KK}<0,20$, Korelasi sangat rendah/ lemah sekali;

3. $0,20<\mathrm{KK}<0,40, \quad$ korelasi rendah/lemah tapi pasti;

4. $0,40<\mathrm{KK}<0,70$, korelasi cukup berarti;

5. $0,70<\mathrm{KK}<0,90$, korelasi yang tinggi, kuat;

6. $0,90<\mathrm{KK}<1,00$, korelasi sangat tinggi, kuat sekali, dapat diandalkan; dan

7. $\mathrm{KK}=1$, korelasi sempurna

Pada penelitian ini R Square yang digunakan adalah Adjusted $\mathrm{R}$ Square karena disesuaikan dengan jumlah variabel yang digunakan dalam penelitian. Ghozali (2005) dalam Arfan (2013), Adjusted $R$ Square dianggap lebih baik dari $\mathrm{R}^{2}$ karena nilai Adjusted $R$ Square dapat naik atau turun apabila satu variabel independen ditambahkan ke dalam model.

b. Pengujian Parsial (Uji t)

Ghozali (2009), uji t pada umumnya menunjukkan seberapa jauh pengaruh satu variabel independen secara individual (parsial) dalam menerangkan variasi variabel dependen. Probabilitas lebih kecil dari 0,05 maka hasilnya signifikan berarti terdapat pengaruh dari variabel independen secara individual terhadap variabel dependen. c. Uji simultan (Uji F)

Ghozali (2009), uji F menunjukkan apakah semua variabel independen yang dimasukkan dalam model mempunyai pengaruh secara bersama-sama terhadap variabel dependen. Probabilitas lebih kecil dari 0,05, maka hasilnya signifikan berarti terdapat pengaruh dari variabel independen secara bersama-sama terhadap variabel dependen.

\section{Hasil Penelitian dan Pembahasan}

\section{Analisis Data}

Analisis data adalah suatu kegiatan untuk meneliti, memeriksa, mempelajari, membandingkan data yang ada dan membuat interpretasi yang diperlukan. Selain itu, analisis data dapat digunakan untuk mengidentifikasi jawaban atas masalah yang telah dirumuskan sebelumnya. Data diperoleh dari penyebaran kuesioner yang dikuantitatifkan agar dapat dianalisis secara statistik.

\section{Analisis Deskriptif}

Analisis deskriptif merupakan analisis yang didasarkan pada hasil jawaban yang diperoleh dari responden, dimana responden memberikan penilaian atas pernyataanpernyataan yang diajukan oleh penulis. Kemudian data yang diperoleh dari jawaban responden atas pernyataan tersebut yang diajukan, selanjutnya dihitung persentasenya.

a. Deskripsi Data

Kuesioner yang berisi 19 item pernyataan ini disebarkan kepada 25 responden yang menjabat sebagai auditor di Inspektorat Kabupaten Luwu Timur. Dalam penelitian ini, peneliti menyebarkan 
kuesioner sebanyak 25 eksemplar dan 24 eksemplar kuesioner yang kembali serta dapat diolah. Jumlah kuesioner kembali dengan data yang dapt diolah adalah sebanyak 24 eksemplar, dimana 1 eksemplar tidak dikembalikan oleh responden.

b. Karakteristik Responden

Untuk memperoleh gambaran tentang karakteristik yang diteliti, dilakukan pengolahan data melalui perhitungan statistik deskriptif. Data yang merupakan jawaban responden dianalisis dengan bantuan program SPSS 21.0 dengan teknik analisis data. Berikut ini disajikan hasil analisis statistic deskriptif yang diperoleh dari jawaban responden atas pernyataan yang diajukan oleh peneliti terhadap beberapa kategori karakteristik responden.
1. Karakteristik Responden Berdasarkan Jenis Kelamin

Data responden berdasarkan jenis kelamin dapat dilihat dalam table 1 berikut ini:

Tabel 1: Jenis Kelamin Responden

\begin{tabular}{|rl|r|r|}
\hline & Frequency & Percent \\
\hline \multirow{4}{*}{ Valid } & Pria & 14 & 58.3 \\
& Wanita & 10 & 41.7 \\
& Total & 24 & 100.0 \\
\hline
\end{tabular}

Sumber:Output SPSS 21.0, 2014

Dari tabel 1 menunjukkan bahwan responden pria dalam penelitian ini berjumlah 14 orang atau $58,3 \%$ lebih besar dibandinkan jumlah responden wanita dalam penelitian ini hanya berjumlah 10 orang atau $41,7 \%$ dari total keseluruhan responden.

Tabel 2: Umur Responden

Umur Responden

\begin{tabular}{|c|c|c|c|c|c|}
\hline & & Frequency & Percent & Valid Percent & Cumulative Percent \\
\hline & $>51$ & 3 & 12.5 & 12.5 & 12.5 \\
\hline & $41-50$ & 8 & 33.3 & 33.3 & 45.8 \\
\hline Valid & $31-40$ & 11 & 45.8 & 45.8 & 91.6 \\
\hline & $21-30$ & 2 & 8.3 & 8.3 & 100.0 \\
\hline & Total & 24 & 100.0 & 100.0 & \\
\hline
\end{tabular}

Sumber:Output SPSS 21.0, 2014 
Dari tabel 2 menunjukkan bahwa responden dalam penelitian ini yang berusia 21-30 tahun berjumlah 2 orang atau 8,3\%, yang berusia 31-40 tahun berjumlah 11 orang atau 45,8\%, yang berusia 41-50 tahun berjumlah 8 orang atau 33,3\% dan berusia diatas 51 tahun berjumlah 3 orang atau 12,5\%.

2. Karakteristik Responden Berdasarkan Pendidikan Akhir

Data responden berdasrkan pendidikan terakhir dapat dilihat dalam tabel 3 berikut ini:

Tabel 3: Pendidikan Terakhir

\begin{tabular}{|rl|r|r|}
\hline & Frequency & Percent \\
\hline \multirow{4}{*}{ Valid } & D3 & 1 & 4.2 \\
& S1 & 17 & 70.8 \\
& S2 & 6 & 25.0 \\
& Total & 24 & 100.0 \\
\hline
\end{tabular}

Sumber:Output SPSS 21.0, 2014

Data tabel 3 di atas menunjukkan bahwa mayoritas responden dalam penelitian ini adalah berpendidikan S1 sebanyak 17 orang atau $70,8 \%$ dan yang berpendidikan S2 sebanyak 6 orang atau 25,0\%.

3. Karakteristik Responden Berdasarkan Masa Bekerja

Data responden berdasarkan masa bekerja dapat dilihat dalam tabel 4 berikut ini:
Tabel 4: Masa Bekerja Responden

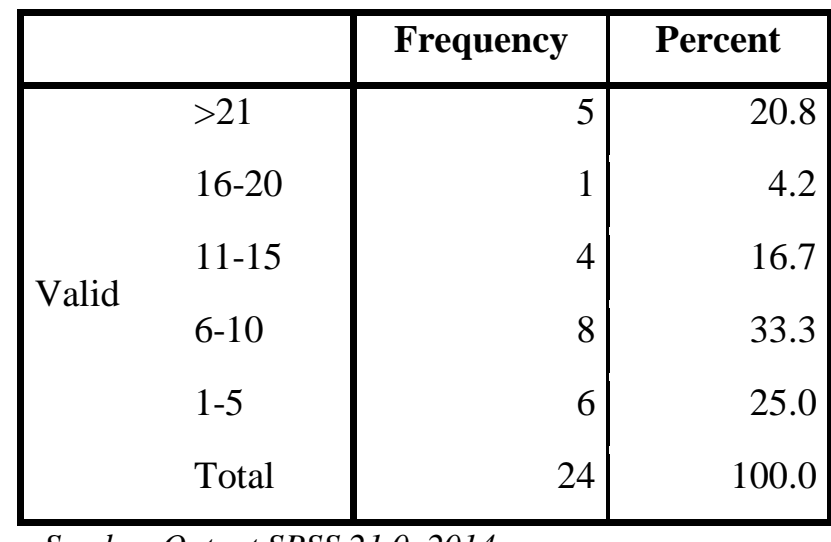

Sumber:Output SPSS 21.0, 2014

Data tabel 4.4 di atas menunjukkan bahwa mayoritas responden dalam penelitian ini adalah responden yang memiliki masa bekerja selama 1-5 tahun sebanyak 6 orang atau 25,0\%, 6-10 tahun berjumlah 8 orang atau 33,3\%, 11-15 tahun sebanyak 4 orang atau 16,7\%, 16-20 tahun sebanyak 1 orang atau 4,2\%, dan di atas 21 tahun sebanyak 6 orang atau $25,0 \%$.

\section{Analisis Jawaban Responden}

Untuk menganalisis jawaban responden terhadap variabel Kompetensi (X1), variabel Independensi (X2) dan variabel Kinerja Auditor (Y), peneliti menggunakan 5 skala likert, yaitu: 1 = Sangat Tidak Setuju (STS)

$2=$ Tidak Setuju $($ TS $)$

$3=\operatorname{Netral}(\mathrm{N})$

$4=$ Setuju (S)

$5=$ Sangat Setuju (SS)

Pernyataan-pernyataan yang terkait dengan variabel dependen dan independen yang terdapat dalam kuesioner, yaitu:

a. Variabel $\left(\mathrm{X}_{1}\right)$ Kompetensi 
Tabel 5

Deskripsi Jawaban Variabel Kompetensi

\begin{tabular}{|c|c|c|c|c|c|c|}
\hline Item & STS & TS & N & S & SS & Total \\
\hline 1 & 0 & 0 & 1 & 9 & 14 & 24 \\
\hline 2 & 0 & 0 & 0 & 9 & 15 & 24 \\
\hline 3 & 0 & 0 & 1 & 21 & 2 & 24 \\
\hline 4 & 0 & 0 & 1 & 14 & 9 & 24 \\
\hline 5 & 0 & 0 & 0 & 20 & 4 & 24 \\
\hline 6 & 0 & 0 & 0 & 11 & 13 & 24 \\
\hline 7 & 0 & 0 & 0 & 15 & 9 & 24 \\
\hline Persentase & 0,00 & 0,00 & 0,43 & 14,14 & 9,43 & 24 \\
\hline
\end{tabular}

Data primer setelah diolah, 2014

Berdasarkan tabel di atas menunjukkan bahwa untuk semua item pernyataan, responden menjawab setuju yang masing-masing persentasenya berturutturut yaitu $9 \%$ responden menjawab setuju bahwa auditor harus mampu berkerjasama dalam tim, 9\% responden menjawab setuju bahwa auditor harus memiliki pengetahuan tentang teori organisasi untuk memahami organisasi, $21 \%$ responden menjawab setuju bahwa auditor harus memiliki pengetahuan auditing dan pengetahuan tentang sektor publik.

Responden yang menjawab setuju yatitu $14 \%$ bahwa auditor harus memiliki pengetahuan tentang akuntansi yang akan membantu dalam mengelolah angka dan data, 20\% responden menjawab setuju bahwa auditor harus memiliki keahlian untuk melakukan wawancara serta kemampuan membaca cepat, $11 \%$ responden menjawab setuju bahwa auditor harus memahami ilmu statistik serta mempunyai keahlian menggunakan komputer, $15 \%$ responden menjawab setuju bahwa auditor memiliki kemampuan untuk menulis dan mempersentasekan laporan dengan baik.

Jadi berdasarkan tabel di atas, maka dapat disimpulkan bahwa sebanyak 14,14\% responden menjawab setuju adanya kompetensi dalam kinerja auditor pemerintah Kabupaten Luwu Timur, 9,43\% responden menjawab sangat setuju adanya kompetensi dalam kinerja auditor pemerintah Kabupaten Luwu Timur, 0,43\% responden menjawab netral adanya kompetensi dalam kinerja auditor pemerintah Kabupaten Luwu Timur.

b. Variabel $\left(\mathrm{X}_{2}\right)$ Independensi 
Tabel 6

Deskripsi Jawaban Variabel Independen

\begin{tabular}{|c|c|c|c|c|c|c|}
\hline Item & STS & TS & N & S & SS & Total \\
\hline 1 & 0 & 0 & 1 & 12 & 11 & 24 \\
\hline 2 & 0 & 0 & 1 & 11 & 12 & 24 \\
\hline 3 & 0 & 0 & 2 & 14 & 8 & 24 \\
\hline 4 & 0 & 0 & 1 & 13 & 10 & 24 \\
\hline 5 & 0 & 0 & 1 & 15 & 8 & 24 \\
\hline 6 & 0 & 0 & 1 & 12 & 11 & 24 \\
\hline 7 & 0 & 0 & 0 & 16 & 8 & 24 \\
\hline 8 & 0 & 0 & 0 & 12 & 12 & 24 \\
\hline Persentase & 0,00 & 0,00 & 0,87 & 13,13 & 10,00 & 24 \\
\hline
\end{tabular}

Data primer setelah diolah, 2014

Berdasarkan tabel di atas menunjukkan bahwa untuk semua item pernyataan, responden menjawab setuju yang masing-masing persentasenya berturutturut yaitu $12 \%$ responden menjawab setuju bahwa penyusunan program audit bebas dari campur tangan pimpinan (inspektur) untuk menentukan, mengeliminasi atau memodifikasi bagian-bagian tertentu yang diperiksa , $11 \%$ responden menjawab setuju bahwa penyusunan program audit bebas dari intervensi pimpinan tentang prosedur yang dipilih auditor.

Responden yang menjawab setuju yaitu $14 \%$ bahwa penyusunan program audit bebas dari usaha-usaha pihak lain untuk menentukan subjek pekerjaan pemeriksaan, $13 \%$ responden menjawab setuju bahwa pelaksanaan pemeriksaan harus bekerjasama dengan manajerial selama proses pemeriksaan, $15 \%$ responden menjawab setuju bahwa pemeriksaan bebas dari kepentingan pribadi maupun pihak lain untuk membatasi segala kegiatan pemeriksaan, $12 \%$ responden menjawab setuju bahwa pelaporan bebas dari kewajiban pihak lain untuk mempengaruhi fakta-fakta yang dilaporkan, $16 \%$ responden menjawab setuju bahwa pelaporan hasil audit bebas dari bahasa atau istilah-istilah yang menimbulkan multi tafsir, $12 \%$ responden menjawab setuju bahwa pelaporan bebas dari usaha pihak tertentu untuk mempengaruhi pertimbangan pemeriksa terhadap isi laporan pemeriksaan Jadi berdasarkan tabel di atas, maka dapat disimpulkan bahwa sebanyak 13,13\% responden menjawab setuju adanya Independensi dalam kinerja auditor pemerintah Kabupaten Luwu Timur, $10,00 \%$ responden menjawab sangat setuju adanya kompetensi dalam kinerja auditor pemerintah Kabupaten Luwu Timur, 0,87\% 
responden menjawab netral adanya

kompetensi dalam kinerja auditor

pemerintah Kabupaten Luwu Timur.

c. Variabel (Y) Kinerja Auditor

Tabel 7

Deskripsi Jawaban Variabel Kinerja Auditor

\begin{tabular}{|c|c|c|c|c|c|c|}
\hline Item & STS & TS & N & S & SS & Total \\
\hline 1 & 0 & 0 & 1 & 18 & 5 & 24 \\
\hline 2 & 0 & 0 & 1 & 9 & 14 & 24 \\
\hline 3 & 0 & 0 & 0 & 14 & 10 & 24 \\
\hline 4 & 0 & 0 & 0 & 15 & 9 & 24 \\
\hline Persentase & 0,00 & 0,00 & 0,50 & 14,00 & 9,50 & 24 \\
\hline
\end{tabular}

Data primer setelah diolah, 2014

Berdasarkan tabel di atas menunjukkan bahwa untuk semua item pernyataan, responden menjawab setuju yang masing-masing persentasenya berturutturut yaitu $18 \%$ responden mejawab setuju bahwa program kerja pemeriksaan tahunan (PKPT) yang dilakukan oleh Inspektorat Kabupaten Luwu Timur setiap tahun tercapai, $9 \%$ responden menjawab setuju bahwa laporan hasil pemeriksaan (LHP) sudah disusun oleh Inspektorat Kabupaten Luwu Timur sesuai dengan aturan-aturan yang ada , 14\% responden menjawab setuju bahwa dalam melakukan pengawasan/pemeriksaan, aparat inspektorat Kabupaten Luwu Timur memahami dan menguasai tugas pokoknya, $15 \%$ responden menjawab setuju bahwa aparat inspektorat Kabupaten Luwu Timur mengerti visi, misi, dan tujuan organisasi.
Dengan demikian dapat disimpulkan bahwa sebanyak 14,00\% responden menjawab setuju bahwa adanya kinerja auditor pada inspektorat kabupaten Luwu Timur.

\section{Uji Kualitas Data}

\section{a. Uji Validitas}

Uji validitas penilitian ini digunakan untuk mengetahui apakah pernyataan pada kuesioner yang telah diedarkan dapat mengukur variabel yang akan diukur.

Untuk mengetahui validitas pernyataan dari setiap variabel, maka digunakan correlation bivariate dengan kriteria:

1. Jika sig. (2-tailed) $<0,05=$ valid

2. Jika sig . (2-tailed) $>0,05=$ tidak valid

\section{Kompetensi}


Tabel 8

Hasil Uji Validitas Variabel Kompetensi

\begin{tabular}{|c|c|c|c|}
\hline Pernyataan & Pearson Correlation & Significant & Keterangan \\
\hline Kompetansi 1 & $0,709^{* *}$ & 0,000 & Valid \\
\hline Kompetansi 2 & $0,795^{* *}$ & 0,000 & Valid \\
\hline Kompetansi 3 & $0,498^{* *}$ & 0,013 & Valid \\
\hline Kompetansi 4 & $0,743^{* *}$ & 0,000 & Valid \\
\hline Kompetansi 5 & $0,476^{* *}$ & 0,019 & Valid \\
\hline Kompetansi 6 & $0,632^{* *}$ & 0,001 & Valid \\
\hline Kompetansi 7 & $0,747^{* *}$ & 0,000 & \\
\hline
\end{tabular}

Data primer setelah diolah, 2014

Independensi

Tabel 9

Hasil Uji Validitas Variabel Independensi

\begin{tabular}{|c|c|c|c|}
\hline Pernyataan & Pearson Correlation & Significant & Keterangan \\
\hline Independensi 1 & $0,732^{* *}$ & 0,000 & Valid \\
\hline Independensi 2 & $0,630^{* *}$ & 0,001 & Valid \\
\hline Independensi 3 & $0,569^{* *}$ & 0,004 & Valid \\
\hline Independensi 4 & $0,694^{* *}$ & 0,000 & Valid \\
\hline Independensi 5 & $0,805^{* *}$ & 0,000 & Valid \\
\hline Independensi 6 & $0,804^{* *}$ & 0,000 & Valid \\
\hline Independensi 7 & $0,686^{* *}$ & 0,000 & Valid \\
\hline Independensi 8 & $0,643^{* *}$ & 0,001 & \\
\hline
\end{tabular}

Data primer setelah diolah, 2014

Kinerja Auditor

Tabel 10

Hasil Uji Validitas Variabel Independensi

\begin{tabular}{|c|c|c|c|}
\hline Pernyataan & Pearson Correlation & Significant & Keterangan \\
\hline Kinerja Auditor 1 & $0,500^{* *}$ & 0,013 & Valid \\
\hline Kinerja Auditor 2 & $0,844^{* *}$ & 0,000 & Valid \\
\hline Kinerja Auditor 3 & $0,598^{* *}$ & 0,002 & Valid \\
\hline Kinerja Auditor 4 & $0,822^{* *}$ & 0,000 & Valid \\
\hline
\end{tabular}

Data primer setelah diolah, 2014 
Berdasarkan tabel uji validitas diatas variabel kompetensi $\left(\mathrm{X}_{1}\right), \quad$ variabel independensi $\left(\mathrm{X}_{2}\right)$ dan variabel kinerja auditor (Y) di atas, dapat disimpulkan bahwa semua item pernyataan untuk masing-masing variabel dinyatakan valid. Hal ini dapat dilihat dari nilai signifikansi untuk setiap pernyataan pada setiap variabel $<0,05$ maka pernyataan dikatakan valid.

Sesuai dengan tujuan dilakukannya uji validitas adalah untuk melihat seberapa besar kemampuan pernyataan dapat mengetahui jawaban responden. Sehingga dapat disimpulkan bahwa semua item pernyataan yang diajukan oleh peneliti dalam kuesioner yang dibagikan kepada responden dapat dijadikan sebagai alat ukur yang tepat.

\section{b. Uji Reliabilitas}

Uji reliabitas dilakukan untuk mengukur handal atau tidaknya kuesioner yang digunakan untuk mengukur variabel penelitian dan untuk mengukur apakah instrumen yang dalam hal ini kuesioner dapat digunakan lebih dari satu kali, paling tidak oleh responden yang sama akan menghasilkan data yang konsisten. Ghozali (2009), Metode yang digunakan untuk mengukur reliabilitas setiap variabel yaitu metode Alpha Cronbach. Suatu instrumen penelitian dikatakan reliabel apabila nilai alpha $>0,60$.

Tabel 11: Hasil Uji Reliabilitas

\begin{tabular}{|c|c|c|}
\hline Variabel & $\begin{array}{c}\text { Koefisien } \\
\text { Alpha }\end{array}$ & Keterangan \\
\hline Kompetensi & 0,788 & Reliabel \\
\hline Independensi & 0,845 & Reliabel \\
\hline Kinerja Auditor & 0,646 & Reliabel \\
\hline
\end{tabular}

Dari hasil uji reliabilitas di atas, semua variabel yang dijadikan instrumen dalam penelitian ini adalah reliabel atau handal karena menunjukkan tingkat reliabilitas yang tinggi. Hal ini dibuktikan dengan nilai koefisien Alpha lebih dari 0,60 sehingga dapat digunakan sebagai alat ukur yang handal atau dapat dipercaya.

\section{Uji Asumsi Klasik}

\section{Uji Normalitas}

Uji normalitas bertujuan untuk menguji apakah dalam sebuah model regresi, variabel dependen, variabel independen atau keduanya mempunyai distribusi normal atau tidak. Dalam penelitian ini uji normalitas yang digunakan adalah grafik histogram dan kurva penyebaran P-plot.

\section{Gambar 1: Grafik Histogram}

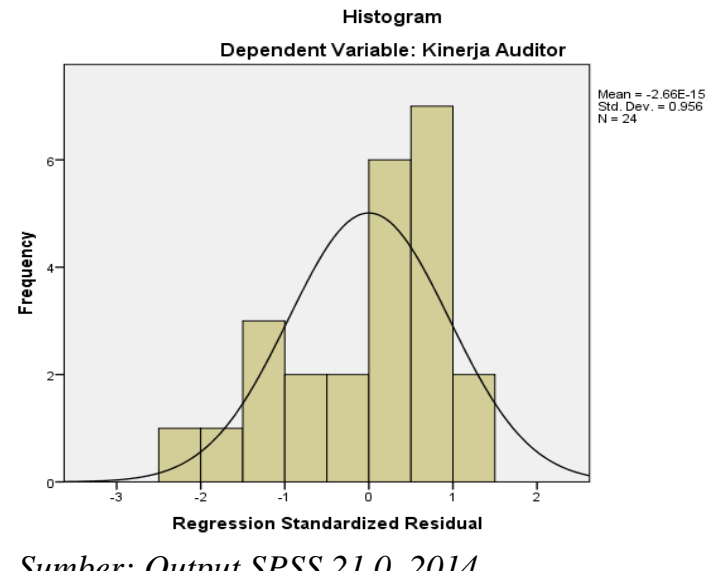

Dengan melihat grafik histogram, dapat disimpulkan bahwa grafik histogram menunjukkan pola distribusi yang mendekati normal, hal ini dibuktikan dengan melihat bahwa grafik membentuk simetris dan mengikuti garis diagonal. Akan tetapi hasil dari grafik histogram ini tidak terlalu akurat apalagi ketika jumlah sampel yang digunakan kecil. 
Metode lain yang dapat memberikan hasil untuk melihat apakah data terdistribusi normal adalah normal probability plot.

\section{Gambar 2: Normal Probalility Plot}

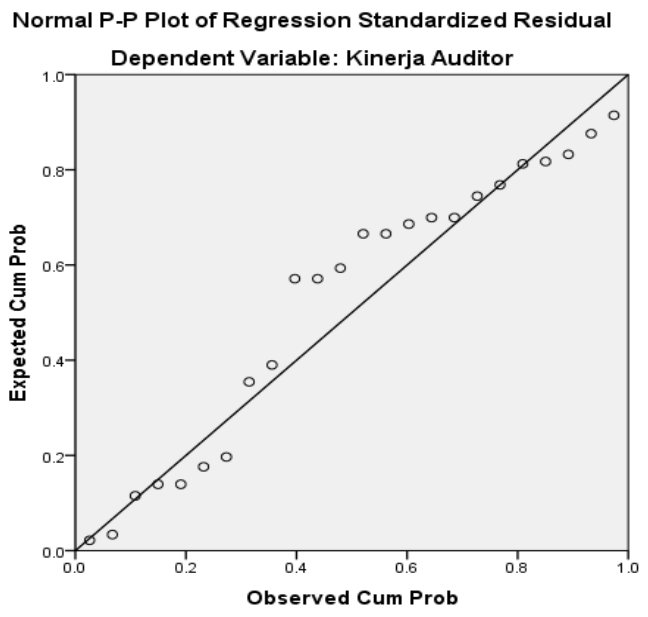

Sumber: Output SPSS 21.0, 2014

Berdasarkan tampilan grafik P-Plot (gambar 4.3) dapat disimpulkan bahwa terlihat titik-titik menyebar di sekitar garis diagonal, serta penyebarannya mengikuti arah garis diagonal, sehingga dapat dikatakan bahwa pola distribusinya normal.

Namun pengujian normalitas data dengan hanya melihat grafik dapat menyesatkan dan tidak memberikan hasil akurat, sehingga perlu melakukan uji normalitas data dengan menggunakan statistik agar lebih meyakinkan. Untuk memastikan apakah data di sepanjang garis diagonal berdistribusi normal, maka dilakukan uji Kolmogrov-Smirnov (1 Sample KS) dengan melihat data residualnya apakah terdistribusi normal atau tidak. Jika nilai signifikansinya lebih besar dari 0,05 maka distribusi data adalah normal.

\section{Uji Multikolinearitas}

Uji ini bertujuan untuk menguji apakah pada model regresi ditemukan adanya korelasi antara variabel independen. Jika terjadi korelasi maka dinamakan terdapat problem multikolinearitas. Model regresi yang baik seharusnya tidak terjadi korelasi diantara variabel independen. Salah satu Metode yang di gunakan untuk mendeteksi adanya multikolinearitas, yaitu dengan melihat tolerance value atau nilai VIF (Variant Inflation Factor). Jika nilai tolerance value dibawah 0,10 atau nilai VIF diatas 10 maka variabel tersebut mempunyai persoalan multikolinearitas dengan variabel bebas yang lainnya.

\section{Tabel 12: Uji Multikolinearitas}

\section{Coefficients $^{\mathrm{a}}$}

\begin{tabular}{|rl|r|r|}
\hline \multirow{2}{*}{ Model } & \multicolumn{2}{|c|}{ Collinearity Statistics } \\
\cline { 2 - 3 } & (Constant) & Tolerance & \multicolumn{1}{c|}{ VIF } \\
\hline \multirow{2}{*}{1} & Kompetensi & .592 & 1.690 \\
& Independensi & .592 & 1.690 \\
\hline
\end{tabular}

a. Dependent Variable: Kinerja Auditor

Berdasarkan tabel 4.12 di atas, model regresi yang diajukan untuk variabel independen semuanya terbebas dari multikolinearitas. Ini terlihat dari nilai variance inflation factor (VIF) masing-masing variabel independen memiliki VIF tidak lebih dari 10 dan tolerance value $>0,10$, maka dapat dinyatakan model regresi linear berganda terbebas dari asumsi multikolinearitas dan variabel independen dapat digunakan untuk mengetahui pengaruhnya terhadap kualitas hasil kerja auditor.

\section{Uji Heterokedastisitas}


Uji heterokedastisitas bertujuan untuk mengetahui apakah dalam sebuah model regresi terjadi ketidaksamaan varian dari residual antara satu pengamatan dengan pengamatan yang lain. Model regresi yang baik adalah yang homokedastisitas atau tidak terjadi heterokedastisitas (Ghozali, 2009:125). Untuk menguji ada tidaknya masalah heterokedastisitas dapat dilakukan dengan melihat apakah terdapat pola tertentu pada grafik scttterplot berikut ini:

\section{Gambar 3: Diagram Scatterplot}

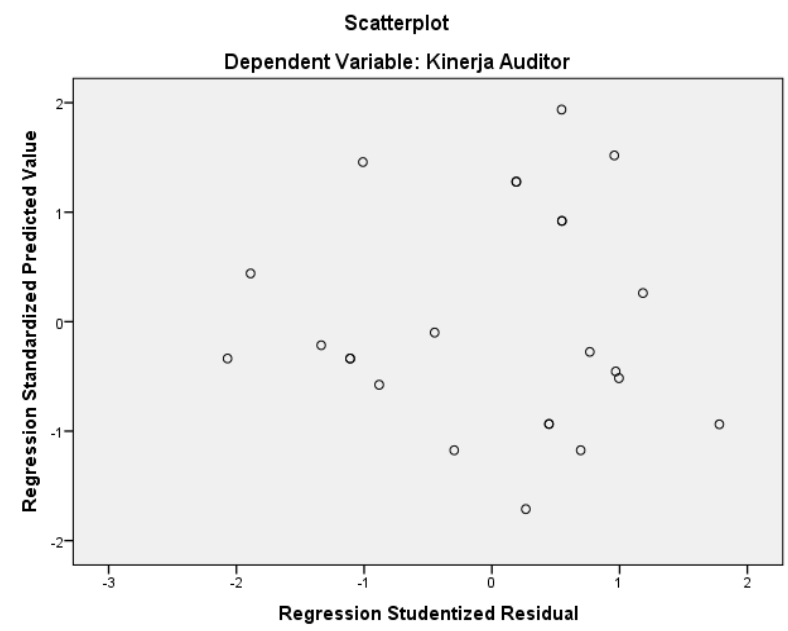

Sumber: Output SPSS 21.0, 2014

Dari tampilan output SPSS grafik scatterplot terlihat bahwa data tersebar secara acak tanpa membentuk suatu pola tertentu serta titik-titiknya menyebar di atas dan di bawah angka 0 (nol) pada sumbu $Y$, ini membuktikan tidak terjadi heterokedastisitas.

Hal ini dapat disimpulkan bahwa dalam model regresi ini terdapat perbedaan varians dari suatu pengamatan ke pengamatan yang lain.

\section{Pengujian Hipotesis}

\section{Uji regresi Linear Berganda}

Uji regresi berganda bertujuan untuk mengetahui ada tidaknya pengaruh variabel independen terhadap variable dependen. Besarnya pengaruh variabel independen terhadap variable dependen secara simultan dapat dihitung melalui suatu persamaan regresi berganda.

\section{Tabel 13: Uji Regresi Linear Berganda}

\section{Coefficients $^{\mathrm{a}}$}

\begin{tabular}{|c|c|c|}
\hline \multirow[t]{2}{*}{ Model } & \multicolumn{2}{|c|}{$\begin{array}{c}\text { Unstandardized } \\
\text { Coefficients }\end{array}$} \\
\hline & B & Std. Error \\
\hline (Constant) & .889 & .773 \\
\hline 1 Kompetensi & .430 & .222 \\
\hline Independensi & .367 & .186 \\
\hline
\end{tabular}

a. Dependent Variable: Kinerja Auditor

Dari tabel di atas dapat diperoleh rumus regresi sebagai berikut:

$\mathrm{Y}=0,889+0,430 \mathrm{X}_{1}+0,367 \mathrm{X}_{2}$

Dari penelitian regresi di atas, konstanta (a) adalah sebesar 0,889 hal ini berarti jika tidak ada perubahan variabel kompetensi $\left(\mathrm{X}_{1}\right)$ dan independensi $\left(\mathrm{X}_{2}\right)$, yang mempengaruhi, maka besarnya kinerja auditor pemerintah daerah kabupaten Luwu Timur 0,889. Sedangkan hasil uji regresi berganda untuk variabel independensi dapat dijelaskan sebagai berikut:

1. Nilai koefisien kompetensi $\left(X_{1}\right)$ sebesar 0,430 berpengaruh positif terhadap kinerja auditor pemerintah daerah (Y). Hal ini menunjukkan bahwa setiap kenaikan kompetensi satu satuan maka variabel kinerja auditor pemerintah daerah naik sebesar 0,430 dengan asumsi bahwa variabel kompetensi yang lain tetap. 
2. Nilai koefisien independensi $\left(\mathrm{X}_{2}\right)$ sebesar 0,367 berpengaruh positif terhadap kinerja auditor pemerintah daerah (Y). Hal ini menunjukkan bahwa setiap kenaikan independensi satu satuan maka variabel kinerja auditor pemerintah daerah naik sebesar 0,367 dengan asumsi bahwa variabel independensi yang lain tetap.

\section{Koefisien Determinasi $\left(\mathbf{R}^{2}\right)$}

Uji ini dilakukan untuk mengukur kemampuan variabel-variabel independen, yaitu kompetensi dan independensi terhadap kinerja auditor pemerintah daerah. Hasil koefisien determinasi dapat dilihat pada kolom adjusted $R$ square, yang ditampilkan pada tabel berikut :

\section{Tabel 14}

\section{Kofisien Determinasi $\left(\mathbf{R}^{2}\right)$}

Model Summary ${ }^{b}$

\begin{tabular}{|l|r|r|r|r|}
\hline Model & R & \multicolumn{1}{|c|}{ R Square } & Adjusted R Square & \multicolumn{2}{|c|}{$\begin{array}{c}\text { Std. Error of the } \\
\text { Estimate }\end{array}$} \\
\hline 1 & $.709^{\mathrm{a}}$ & .502 & .455 & .26672 \\
\hline
\end{tabular}

a. Predictors: (Constant), Independensi, Kompetensi

b. Dependent Variable: Kinerja Auditor

Pada tabel di atas menunjukkan bahwa nilai koefisien adjusted $R$ square adalah sebesar 0,455 atau 45,5\%. Maka disimpulkan bahwa variabel dependen yaitu kinerja auditor pemerintah daerah $(\mathrm{Y})$ dipengaruhi oleh kompetensi $\left(\mathrm{X}_{1}\right)$ dan independensi $\left(\mathrm{X}_{2}\right)$ adalah sebesar 45,5\%. Sedangkan sisanya $54,5 \%$ dipengaruhi oleh variabel lain yang tidak dimasukkan dalam penelitian ini.

Angka koefisien korelasi (R) pada tabel 14 sebesar 0,709 menunjukkan bahwa hubungan antara variabel independen dengan variabel dependen adalah kuat karena memiliki nilai koefisien korelasi di atas 0,5.

\section{Uji Parsial (Uji t)}

Pengujian regresi secara parsial (uji t) bertujuan untuk menguji pengaruh dari masing- masing variabel independen secara parsial terhadap variabel dependen. Untuk mengetahui bagaimana pengaruh dari masing-masing variabel independen terhadap variabel dependen dapat dilihat dengan membandingkan nilai probabilitas ( $p$-value ) dari masing-masing variabel dengan tingkat signifikansi yang digunakan sebesar 0,05. Jika p-value lebih kecil dari 0,05 maka ini menunjukkan bahwa variabel-variabel independen secara parsial mempunyai pengaruh signifikan terhadap variabel dependen. 
Tabel 15

Hasil Pengujian Parsial (Uji t)

Coefficients $^{\mathrm{a}}$

\begin{tabular}{|l|r|r|r|r|r|}
\hline Model & \multicolumn{2}{|l|}{ Unstandardized Coefficients } & \multicolumn{1}{|c|}{$\begin{array}{c}\text { Standardized } \\
\text { Coefficients }\end{array}$} & \multicolumn{1}{c|}{ Sig. } \\
\cline { 2 - 4 } & \multicolumn{1}{|c|}{$\mathrm{B}$} & Std. Error & \multicolumn{1}{c|}{ Beta } & & \\
\hline (Constant) & .889 & .773 & & 1.150 & .263 \\
Kompetensi & .430 & .222 & .387 & 1.935 & .067 \\
Independensi & .367 & .186 & .395 & 1.974 & .062 \\
\hline
\end{tabular}

a. Dependent Variable: Kinerja Auditor

Hasil pengujian antara variabel independen terhadap variabel dependen secara individu (parsial) yang dilakukan dengan uji $\mathrm{t}$ (tabel 15) adalah sebagai berikut:

1. Hipotesis kedua menyatakan bahwa kompetensi berpengaruh terhadap kinerja auditor pemerintah daerah. Dari tabel 4.15 dapat diketahui bahwa hasil pengujian untuk variabel kompetensi mempunyai probabilitas signifikansi 0,067 dimana nilai tersebut lebih besar dari 0,05. Dengan demikian $\mathrm{H}_{2}$ ditolak, hal ini berarti bahwa kompetensi tidak mempunyai pengaruh yang signifikan terhadap kinerja auditor pemerintah daerah.

2. Hipotesis kedua menyatakan bahwa independensi berpengaruh terhadap kinerja auditor pemerintah daerah. Dari tabel 4.15 dapat diketahui bahwa hasil pengujian untuk variabel independensi mempunyai probabilitas signifikansi 0,062 dimana nilai tersebut lebih besar dari 0,05. Dengan demikian $\mathrm{H}_{3}$ ditolak, hal ini berarti bahwa kompetensi tidak mempunyai pengaruh yang signifikan terhadap kinerja auditor pemerintah daerah.

\section{Pengujian Simultan ( Uji F )}

Pengujian ini dilakukan untuk mengetahui pengaruh seluruh variabel independen secara bersama-sama atau simultan terhadap variabel dependen dengan menggunakan uji $\mathrm{F}$ dengan tarif signifikansi 5\%. Jika nilai signifikansi uji $\mathrm{F}$ lebih kecil dari 5\% maka terdapat pengaruh antara semua variabel independen terhadap variabel dependen. Hasil pengujian uji $\mathrm{F}$ dapat dilihat pada tabel berikut ini: 
Tabel 16

\section{Hasil Pengujian Simultan (Uji F)}

ANOVA $^{\mathrm{a}}$

\begin{tabular}{|l|r|r|r|r|r|}
\hline Model & Sum of Squares & Df & Mean Square & F & Sig. \\
\hline Regression & 1.506 & 2 & .753 & 10.586 & $.001^{\mathrm{b}}$ \\
1 Residual & 1.494 & 21 & .071 & & \\
\multicolumn{1}{|c|}{ Total } & 3.000 & 23 & & & \\
\hline
\end{tabular}

a. Dependent Variable: Kinerja Auditor

b. Predictors: (Constant), Independensi, Kompetensi

Dari tabel 16 di atas diketahui hasil uji $\mathrm{F}$ menunjukkan bahwa $\mathrm{F}$ hitung adalah 10,586 dengan tingkat signifikansi $0,001^{\mathrm{b}}$. Karena tingkat signifikansi lebih kecil dari $\alpha(0,001<0,05)$ maka $\mathrm{H}_{1}$ diterima. Dengan demikian dapat disimpulkan bahwa semua variabel independen dalam penelitian ini secara bersama-sama (simultan) berpengaruh signifikan terhadap variabel dependen yaitu kinerja auditor pemerintah daerah. Hal ini berarti jika kompetensi $\left(\mathrm{X}_{1}\right)$ dan independensi $\left(\mathrm{X}_{2}\right)$ secara bersama-sama meningkat, maka kinerja auditor pemerintah daerah (Y) juga akan meningkat. Dan sebaliknya, jika kompetensi $\left(\mathrm{X}_{1}\right)$ dan kompetensi $\left(\mathrm{X}_{2}\right)$ secara bersama-sama menurun, maka kinerja auditor pemerintah daerah (Y) juga akan menurun.

\section{Pembahasan Hasil Penelitian}

Pada pengujian hipotesis diperoleh hasil bahwa kompetensi dengan indikator mutu personal, pengetahuan umum dan keahlian khusus, independensi dengan indikator penyusunan program, pelaksanaan pekerjaan dan pelaporan, secara simultan berpengaruh signifikan terhadap kinerja auditor dengan indikator hasil dan perilaku.
Hal ini dapat disebabkan karena untuk meningkatkan kinerja auditor pemerintahan seorang auditor harus memiliki tanggung jawab yang penuh dalam memberikan suatu laporan audit yang di mana tanggung jawab tersebut yaitu memiliki kompetensi auditor yang harus memadai dan berkesinambungan terhadap instansi yang diaudit serta bersikap independen terhadap kepentingan antara auditor terhadap instansi yang diaudit, dengan kata lain bahwa semakin baik/tinggi kompetensi dan sikap independensi yang dimiliki auditor pemerintah dapat memberikan kontribusi yang baik/tinggi terhadap kinerja inspektorat dalam menjalankan tugasnya. Hasil ini sejalan dengan penelitian yang dilakukan oleh Yusri (2013:115) yang menyatakan bahwa kompetensi, independensi dan sikap profesioal secara bersama-sama (simultan) berpengaruh terhadap kualitas audit dalam meningkatkan kinerja Inspektorat.

\section{Hasil Uji Parsial Pengaruh Kompetensi (X1) terhadap Kinerja Auditor Pemerintah Daerah.}

Dari hasil uji parsial yang telah dilakukan antara variabel kompetensi (X1) terhadap kinerja auditor pemerintah daerah menunjukkan bahwa $\mathrm{t}_{\text {hitung }}$ sebesar 1,935 dengan nilai signifikansi 
sebesar 0,067 > 0,05 dan hasil uji regresi berganda menunjukkan nilai koefisien 0,430 diperoleh hasil bahwa variabel kompetensi berpengaruh positif namun tidak signifikan terhadap kinerja auditor pemerintah daerah. Ketidaksignifikan disebabkan karena pada proses audit yang dilakukan oleh inspektorat kabupaten luwu timur dapat dipahami bahwa kinerja auditor tidak bergantung pada kompetensinya. Sehingga dapat disimpulkan bahwa auditor sering kali mendapatkan kesulitankesulitan sehingga kinerja auditoryang dihasilkan akan rendah pula.

Namun, Kompetensi audit yang tidak memberikan pengaruh signifikan dapat memberikan pengaruh positif terhadap kinerja auditor, yaitu bahwa semakin baik/tinggi kompetensi yang dimiliki seorang maka kinerja auditor pemerintah kabupaten Luwu Timur juga semakin baik/tinggi hal ini dapat dibuktikan dengan laporan hasil pemeriksaan BPK provinsi Sulawesi Selatan untuk tahun anggaran 2013 yang memberikan opini audit wajar tanpa pengeculian (BPK Sul-Sel,2014)

Hasil penelitian ini tidak sejalan dengan penelitian yang dilakukan oleh Efendy (2010:71) yang berjudul Pengaruh Kompetensi, Independensi, dan Motivasi Terhadap Kualitas Audit Aparat Inspektorat Dalam Pengawasan Keuangan Daerah. Hasil penelitiannya menunjukkan bahwa kompetensi berpengaruh signifikan terhadap kualitas audit aparat inspektorat.

Hasil Uji Parsial Pengaruh Independensi (X2) Terhadap Kinerja Auditor pemerintah Daerah (Y)
Dari hasil uji parsial yang telah dilakukan antara variabel independensi (X1) terhadap variabel kinerja auditor pemerintah daerah (Y) menunjukkan bahwa $t_{\text {hitung }}$ sebesar 1,974 dengan nilai signifakansi sebesar 0,062 > 0,05 dan hasil uji regresi berganda menunjukkan nilai koefisien 0,367 diperoleh hasil bahwa variabel independensi berpengaruh positif namun tidak signifikan terhadap kinerja.

Sehingga dapat disimpulkan bahwa independensi auditor pemerintahan dalam penelitian ini tidak mempengaruhi kinerja auditor secara signifikan. Dalam penelitian dapat disimpulkan bahwa semakin baik/tinggi independensi auditor pemerintah pada inspektorat kabupaten Luwu Timur maka dapat menyebabkan kinerja auditor juga semakin baik/tinggi. Namun hal tersebut tidak memberikan pengaruh yang signifikan karena sering kali auditor dapat menyebabkan salah saji laporan audit selain itu diduga bahwa independensi aparat inspektorat kabupaten Luwu Timur masih terpengaruh dengan penentu kebijakan. Artinya pada saat penyusunan program pemeriksaan masih ada intervensi pimpinan untuk menentukan, mengeliminasi atau memodifikasi bagian-bagian tertentu yang akan diperiksa serta intervensi atas prosedur-prosedur yang dipilh auditor. Meskipun aparat sering kali mendapat fasilitas dari instansi yang diaudit, namun aparat tetap menganggap bahwa audit yang baik tetap harus dilaksanakan

Hasil penelitian ini sejalan dengan penelitian yang dilakukan oleh Efendy (2010:73) yang menyatakan bahwa independensi tidak berpengruh signifikan terhadap kualitas audit. 


\section{Simpulan}

Berdasarkan pembahasan hasil penelitian, maka dapat ditarik kesimpulan bahwa :

1. Kompetensi dan Independensi secara parsial tidak berpengaruh signifikan terhadap kinerja auditor pemerintah daerah.

2. Dari pengujian secara simultan (uji F), menunjukkan bahwa kompetensi dan independensi berpengaruh secara simultan terhadap kinerja auditor pemerintah daerah.

3. Dari nilai koefisien adjusted $\mathrm{R}$ square adalah sebesar 0,455, ini menunjukkan bahwa $45,5 \%$ kinerja auditor pemerintah daerah dipengaruhi oleh kompetensi dan independensi. Sedangkan sisanya $54,5 \%$ dipengaruhi oleh variabel lain yang tidak dimasukkan dalam penelitian ini.

\section{Saran}

Berdasarkan hasil penelitian yang telah dilakukan, maka peneliti dapat mengemukakan beberapa saran sebagai berikut :

1. Dari hasil penelitian yang dilakukan kompetensi dan indenpendensi berpengaruh secara simultan terhadap kinerja auditor pemerintah daerah, oleh karena itu pemerintah daerah Kab. Luwu Timur harus terus memperhatikan peningkatan kompetensi dan indenpendensi masing-masing auditor pemerintah agar dapat meningkatkan kinerja Auditor yang ada pada pemerintah daerah Kab. Luwu Timur.

2. Peneliti juga menyarankan untuk penelitian selanjutnya agar memperluas objek penelitian pada aparat inspektorat kabupaten/kota seSulawesi Selatan,sehingga hasilnya dapat digeneralisasi.
3. Pada penelitian ini, variabel kompetensi dan independensi yang diteliti berpengaruh terhadap variabel kinerja auditor pemerintah kabupaten Luwu Timur sebesar 45,5\%, berarti bahwa ada pengaruh sebesar 54,5\% dari variabel-variabel lain di luar model. Penelitian selanjutnya disarankan untuk meneliti pengaruh variabel-variabel lain yang belum termasuk dalam model regresi pada penelitian ini, seperti Obyektivitas, Integritas, Akuntabilitas, dan sebagainya.

\section{Daftar Pustaka}

Alim, Hapsari, dan Purwanti. 2007. Pengaruh Kompetensi dan Independensi terhadap Kualitas Audit dengan Etika Auditor sebagai Variabel Moderasi.Simposium Nasional Akuntansi X. Makassar.

Amrin, Arfan. 2013. Pengaruh Karakteristik Perusahaan Terhadap Tingkat Pengungkapan Wajib Pada Laporan Keuangan Perbankan Syariah Indonesia. Skripsi STIE Muhammadiyah Palopo. Palopo.

Arens, Elder, Randal, Beasley, dan Mark. 2008. Auditing and Assurance Service an Integrated Approach. 12th Edition, Upper Sadel River, New Jersey, Pearson Education International.

Arifah, Nurul. 2012. Pengaruh Independensi Auditor, Komitmen Organisasi dan Gaya Kepemimpinan Terhadap Kinerja Auditor. Skripsi Universitas Hasanuddin. Makassar.

Astasari, Voni. 2011. Peranan Audit Operasional Dalam Meningkatkan Efektifitas Kegiatan Perkreditan. Skripsi Universitas Andalas. Padang.

Dalmy, Darlisman. 2009. Pengaruh SDM, Komitmen, motivasi terhadap kinerja auditor dan reward sebagai variabee moderating pada inspektorat provinsi jambi. tesis fakultas ekonomi universitas Sumatra utara. Medan. 
Efendy, Muh. Taufik. 2010. Pengaruh Kompetensi, Independensi, Dan Motivasi Terhadap Kualitas Audit Aparat Inspektorat Dalam Pengawasan Keuangan Daerah. Tesis Universitas Diponegoro. Semarang.

Elfarini, Eunike Christina. 2007. Pengaruh Kompetensi dan Independensi Auditor Terhadap Kualitas Audit (Studi Empiris Pada Kantor Akuntan Publik di Jawa Tengah). Skripsi S1. Universitas Negeri Semarang.

Falah. 2005. Pengaruh Budaya Etis Organisasi dan Orientasi Etika terhadap Sensitivitas Etika.Tesis tidak dipublikasikan.Universitas Diponegoro. Semarang.

Ghozali, Imam. 2009. Aplikasi Analisis Multivariate dengan Program SPSS. Semarang: Badan Penerbit Universitas Diponegoro.

Gondodiyoto, Sanyoto. 2007. Audit Sistem Informasi: Pendekatan CobIT. Mitra Wacana Media. Jakarta.

Irawati. St. Nur 2011. Pengaruh Kompetensi dan Independensi Auditor Terhadap Kualitas Audit Pada Kantor Akuntan Publik di Makassar.Skripsi Universitas Hasanuddin. Makassar.

Kharismatuti, Norma. 2012. Pengaruh Kompetensi dan Independensi Terhadap Kualitas Audit Dengan Etika Auditor Sebagai Variabel Moderasi. Skripsi Universitas Diponegoro. Semarang.

Mahsun. 2007. Akuntansi Sektor Publik. Edisi Kedua. BPFE: Yogyakarta.

Mardiasmo. 2005. Akuntansi Sektor Publik Edisi 2. Penerbit Andi. Yogyakarta.

Marganingsih, Arywarti dan Dwi Martani (2009). Analisis Variabel Anteseden Perilaku Auditor Internal dan Konsekuensinya Terhadap Kinerja: Studi Empiris pada Auditor di Lingkungan Aparat Pengawasan Intern Pemerintah -
Lembaga Pemerintah Non Departemen. SNA XII Palembang.

Mulyadi. 2010. Auditing. Jilid I, Cetakan ke Tujuh, Jakarta: Salemba Empat.

Nugrahaningsih. 2005. Analisis Perbedaan Perilaku Etis Auditor di KAP dalam Etika Profesi (Studi Terhadap Peran Faktorfaktor Individual: Locus of Control, Lama Pengalaman Kerja, Gender dan Equity Sensitivity). SNA VIII Solo. p. 617-630

Rohman. 2007. Pengaruh Peran Manajerial Pengelola Keuangan Daerah dan Fungsi Pemeriksaan Intern terhadap Kinerja Pemerintah Daerah.Jurnal Manajemen Akuntansi dan Sistem Informasi Vol. 7 No. 2.

Sapariyah, Ani. 2011. Pengaruh Good Governance dan Independensi Auditor terhadap Kinerja auditor dan Komitmen Organsisasi. Skripsi STIE AUB. Surakarta.

Sekaran, Uma. 2006. Research Method For Business (Metodologi Penelitian Untuk Bisnis). Buku 1 dan 2. Edisi Empat. Jakarta: Salemba Empat.

Sugiyono. 2007. Metode Penelitian Kuantitatif, Kualitatif dan $R \& D$. Bandung: CV. Alfabeta.

Sri Lastanti, Hexana. 2005. Tinjauan Terhadap Kompetensi dan Independensi Akuntan Publik : Refleksi Atas Skandal Keuangan. Media Riset Akuntansi,Auditing dan Informasi Vol.5 No.1 April.

Tampubolon. 2005. Risk and Systems-Based Internal Audit.Penerbit Elex MediaKomputindo. Jakarta

Trisnaningsih. 2007. Jurnal. Independensi Auditor Dan Komitmen Organisasi Sebagai Mediasi Pengaruh Pemahaman Good Governance, Gaya Kepemimpinan Dan Budaya Organisasi Terhadap Kinerja Auditor. SNA X Makassar. 
Widyananda, Herman. 2008. Revitalisasi Peran Internal Auditor Pemerintah Untuk Penegakan Good Governance di Indonesia. Publikasi, Seminar, makalah, dan Sambutan. Universitas Padjadjaran. Bandung.

Yusman. 2013. Analisis Sistem Informasi Keuangan Daerah dengan Menggunakan Technology Acceptance Model Pada Pemerintah Daerah Kabupaten Sinjai. Skripsi Universitas Hasanuddin. Makassar.

Yusnita. 2010. Pengaruh Kompetensi Dan Independensi Auditor Intern terhadap Kualitas Hasil Pemeriksaanya. Jurnal Akuntansi.,Vol. 5, No. 1-10.

Yusri, Arif. 2013. Pengaruh Faktor Kompetensi, Independensi Dan Sikap Profesional Auditor Terhadap Kualitas Audit Dalam Meningkatkan Kinerja Inspektorat. Skripsi Universitas Hasanuddin. Makassar. 